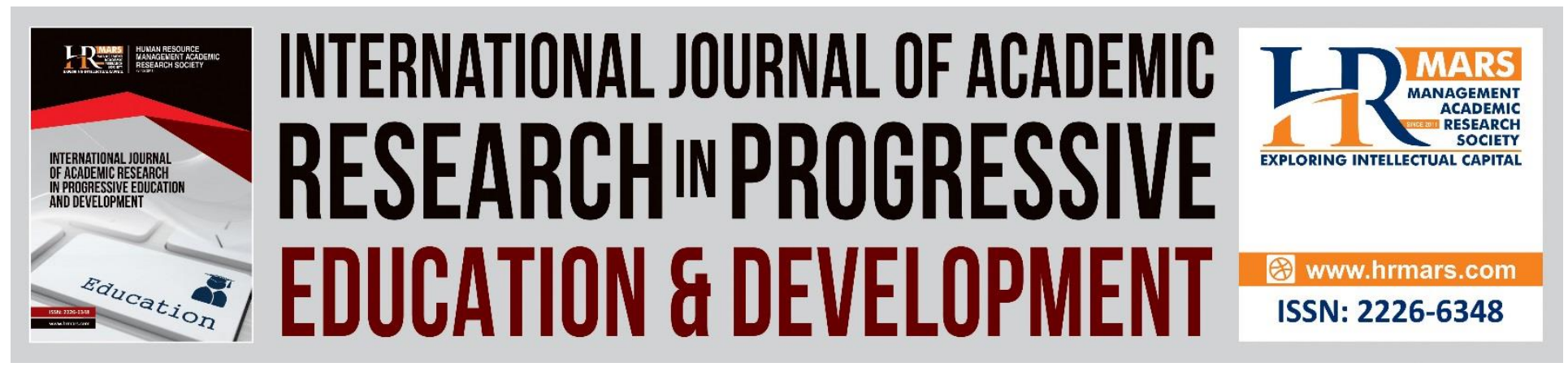

\title{
ECOPRENEUR: A Flipped Classroom Method for Learning Principles of Entrepreneurship for Online Direct Learning
}

\author{
Md Razak, M, I, Alice Shanthi, A., Sheela Paramasivam, Geraldine De Mello, \\ Julina Munchar, Kaarhiyainy Supramaniam
}

To Link this Article: http://dx.doi.org/10.6007/IJARPED/v9-i2/7751

DOI:10.6007/IJARPED/v9-i2/7751

Received: 01 May 2020, Revised: 29 May 2020, Accepted: 16 June 2020

Published Online: 26 July 2020

In-Text Citation: (Razak, et. al., 2020)

To Cite this Article: Razak, M. M. I., Shanthi, A. A., Paramasivam, S., De Mello, G., Munchar, J., \& Supramaniam, K. (2020). Industrial Design Graduates' Perspective on E-Learning in Higher Education. International Journal of Academic Research in Progressive Education \& Development. 9(2), 747-763.

Copyright: (C) 2020 The Author(s)

Published by Human Resource Management Academic Research Society (www.hrmars.com)

This article is published under the Creative Commons Attribution (CC BY 4.0) license. Anyone may reproduce, distribute, translate and create derivative works of this article (for both commercial and non-commercial purposes), subject to full attribution to the original publication and authors. The full terms of this license may be seen

at: http://creativecommons.org/licences/by/4.0/legalcode

\section{Vol. 9(2) 2020, Pg. 747 - 763}

Full Terms \& Conditions of access and use can be found at http://hrmars.com/index.php/pages/detail/publication-ethics 


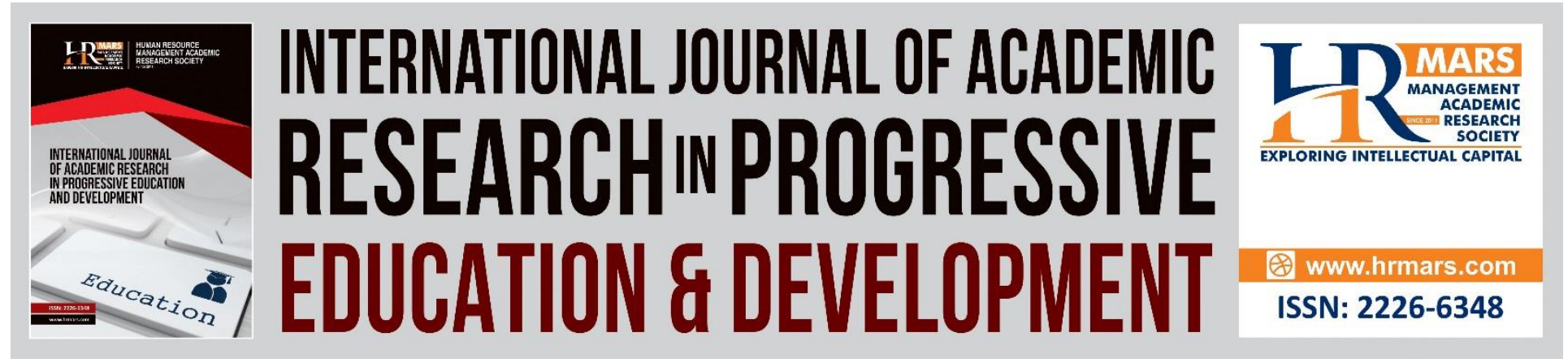

\title{
ECOPRENEUR: A Flipped Classroom Method for Learning Principles of Entrepreneurship for Online Direct Learning
}

\author{
Md Razak, M, I' , Alice Shanthi, A. ${ }^{2}$, Sheela Paramasivam², \\ Geraldine De Mello ${ }^{3}$, Julina Munchar ${ }^{4}$, Kaarhiyainy \\ Supramaniam ${ }^{4}$
}

${ }^{1}$ Universiti Teknologi MARA Melaka Kampus Jasin, Negeri Sembilan, 77300 Merlimau, Melaka, Malaysia, ${ }^{2}$ Universiti Teknologi MARA, Kampus Seremban, 70300, Seremban, Negeri Sembilan,

Malaysia, ${ }^{3}$ Universiti Teknologi MARA Melaka Kampus Lendu, 78000 Alor Gajah Melaka, Malaysia, ${ }^{4}$ Universiti Teknologi MARA, 40450 Shah Alam, Selangor, Malaysia

Email: aliceshanthi@uitm.edu.my

\begin{abstract}
Flipped classroom method with the infusion of interactive digital media into teaching and learning has altered instructional strategies in educational institutions. In this study, the flipped classroom method was conducted online using the ECOPRENEUR learning portal which can be reached at http://digitent.my/. The online learning platform was used to teach Principles of Entrepreneurship (ENT 600) over one semester. This study describes the use of a completely virtual flipped classroom which differs than a blended mode that involves online and face-toface meetings. Eighty-eight students took part in this study. Three instruments comprising survey, structured interview, and students' final grade for the subject were used to gauge students' perception and outcome of using the flipped classroom method in the ECOPRENEUR learning portal. The results show a positive response to the flipped learning using the ECOPRENEUR learning portal.
\end{abstract}

Keyword: Flipped Classroom, Online Direct Learning.

\section{Introduction}

The COVID-19 pandemic has sparked a worldwide shift in today's academic structure. Classes went from physical to complete virtual mode. Online teaching and learning evolved at an unprecedented rate for both teachers and learners. Educators were left with the challenge to maintain student interest in learning and keeping the passing rate high. In answer to this challenge, a group of lecturers teaching the economic subject specifically Principles of Entrepreneurship (ENT 600) turned to the fully online flipped classroom method to teach the 
subject. The lecturers created a learning portal called ECOPRENEUR which adopted the flipped classroom method.

The flipped classroom teaching model was an innovation of J. Wesley Baker, a professor at Cedarville University, Ohio. He placed his teaching notes (PowerPoint slides) in a digital platform and had his students go through the teaching materials before real class time. While in class time was typically used for the applications and practices new concepts that the students acquired beforehand through collaborative activities (Vuong, Tan, \& Lee, 2018). Therefore, a flipped classroom is the reverse to the traditional teaching methods. Traditionally, a course instructor lectures on a topic and assigns work that reinforces the information of the particular topic. However, in a flipped classroom, the instruction is delivered online using videos. As such, learning also occurs outside class as the resources available online such as recorded lectures can be paused, watched and repeated as needed.

The flipped lesson used in ECOPRENEUR learning portal enables students to have 24/7 access to content delivered directly from the lecturer teaching this subject. Students can learn at their own pace and time even beyond class time. During the online class time, the lecturer can focus on answering students' questions, focusing on small group discussion based on students' level, and learning preferences instead of just focussing on lecturing the subject. Class time is spent for deeper discussion, peer learning and teamwork that leads to creation of knowledge (Ganguly, 2019). The benefit of the flipped classroom is that lecturers have more one-on-one time to help students and explain difficult concepts. If problems are difficult for a student to work through, the lecturer could step in to help and explain. If students have questions about the video or online presentation, they can use class time to get questions answered (Kim, Jung, de Siqueira \& Huber, 2016).

This paper is an attempt to describe a fully online flipped classroom method used in teaching an economic subject; Principles of Entrepreneurship (ENT 600) at a local university and to gauge students' perception, as well as the actual efficacy of learning the subject ENT600 using ECOPRENEUR fully online. Flipped classrooms is usually used as a blended learning mode that incorporates both online and face-to-face learning. Therefore, there is a gap on whether flipped classroom learning can be carried out fully online and bring about the learning outcomes. Hence the aim of this paper is to (1) investigate learners' perception on flipped classroom learning using the ECOPRENEUR learning portal and (2) investigate the effects of a completely online flipped classroom learning on the ability of learners to produce their final report.

\section{Problem Statement}

In UiTM lecturers teaching the code ENT600 were left with the challenge to maintain students' interest to learn via online. Teaching and learning online during the COVID-19 pandemic has become a challenge for both lecturers and students. Research shows that online interaction has to be engaging and exciting to attract students to learn online (Shanthi, Thayalan, \& Suppiah, 2019; Shanthi, Thayalan, \& Xavierine, 2018). The normal lecturer method done online where the lecturer and students meet at a designated time and one-way knowledge transmission from the 
lecturer to students might not be the way to reach out to students. One of the biggest problems of learning in a fully online mode is where some students learn nothing at all because they cannot follow the online teaching and that leads to higher failure rates among students (Shanthi, Thayalan \& Xavierine, 2017).The focus of this research is to close the gap between teaching and learning ability by using the fully online flipped classroom. The teaching materials were parked in the ECOPRENEUR learning portal. These teaching materials were arranged according to topics in the portal that can be reached at http://digitent.my. Students can watch the videos and go through the resources found on the portal, anywhere and at any time. The learners' final results for ENT600, perceptions towards the use of these multimedia-learning instructions are recorded and reported in this paper.

\section{Theoretical Frameworks}

In a flipped classroom, the learning activities that traditionally occur in the classroom, like the introduction of new material through lectures and handouts, are introduced to students outside the classroom in a digital environment; The activities that traditionally occur outside the classroom, like homework assignments and activities completed in isolation, are now completed inside the classroom. When students carry out activities and assignments in a more deeper and critical discussion with their teacher and/or their peers, they engage in active learning (Vuong et al., 2018). Usually, videos of topic are created and distributed online as pre-learning exercise. Therefore, the flipped classroom when viewed from the angle of Bloom's Taxonomy, theoretical knowledge is received outside the class at the two lower orders of the taxonomy which is remembering and understanding. The implementation of the knowledge received outside is done in the classroom with the guidance of the teachers via interactions between the students or between student and teacher. At this stage students make decisions about the information learnt outside the classroom and begin to create their own outcomes by using the other four higher order thinking skills namely applying, analyzing, evaluating and creating to complete the in-class tasks or subject assignments. Figure 1.0 depicts a traditional and a flipped Blooms Taxonomy model. 


\section{Traditional Model}

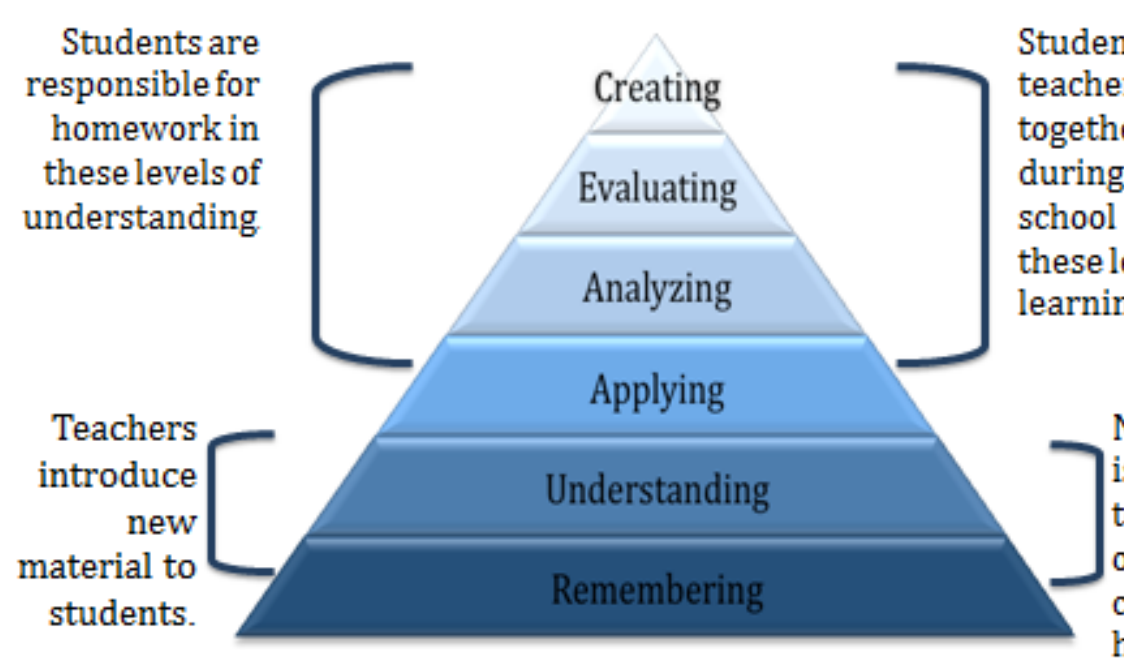

\section{Blooms Taxonomy}

Source: Williams, Beth (2013). How I flipped my classroom. NNNC Conference, Norfolk, NE Figure 1.0 A traditional and a flipped model of Blooms Taxonomy

Flipped classroom learning allows students to work directly with their peers on activities thus allowing for group work and sharing of ideas. A core element in the learning process in flipped classroom as described by $\mathrm{Xu}$ and Shi (2018) is being "more than reflecting on one's own experiences and thoughts about those experiences, but also incorporating others' ideas about the experience as well in order to construct more wholesome knowledge". This promotes both self-directed learning and teamwork.

\section{Literature Review}

Among the key concerns in higher education today is that instructors are not tapping into the digital learning approaches of their students (Kim, Jung, de Siqueira, \& Huber, 2016). In the midst of ongoing concerns and calls for online direct learning, several potential solutions have been offered including the implementation of the flipped classroom learning method (Ganguly, 2019; O'Flaherty, \& Phillips, 2015). By creating an online platform, educators can reach out to students more efficiently and effectively through chat groups, video meetings, and also document sharing (Ganguly, 2019). DeGrazia, Falconer, Nicodemus and Medlin (2015) note that students supplied with optional video lectures came to class much better prepared than when they had been given textbook readings. According to O'Flaherty, \& Phillips (2015), college students do not generally complete reading assignments. However, when materials are in a form of short video, online resource followed by pre-class quiz on the lecture materials proved to be a better combination to get students to explore the materials posted only. This was thought as a highly successful 
practice. The same study revealed that students preferred shorter videos and liked interactive class time where they get to complete tasks assigned through group discussion more than individual task.

This method of teaching using digital platform help students "integrate into student's digital life", help students learn with understanding, increases student engagement and peer learning rather than a rote method (Ganguly, 2019). Studies have also shown that flipped classroom where materials are parked in a digital platform enabled students to learn faster online; as online learning requires $40-60 \%$ less time to learn than in a traditional classroom setting. Students can learn at their own pace, re-read, skip or accelerate through concepts as they choose. Research shows that on average, students retain $25-60 \%$ more material when learning online compared to only $8-10 \%$ in a classroom (Chernev, 2020; Kim et, al. 2016; O'Flaherty, \& Phillips, 2015). On the other hand, studies have found that when attending the flipped courses, students are found to face several obstacles, for instance, Vuong et al. (2018), stated that the an increased time spent on out-of-class planning time may have an detrimental impact on the satisfaction rate of the students as the heavy workload of pre-class activities could overpower the time at home for the students. Kim et, al. (2016) mentioned that students and their instructors (Perinpasingam, Chin \& Supramaniam, 2019) who were used to the traditional lecture methods had initially found it difficult to adapt to a creative style of teaching with new practices, roles and expectations.

\section{Instructional Design}

In this study, the fully online flipped classroom learning was implemented for the subject Principles of Entrepreneurship (ENT 600) during the online direct learning (ODL) carried out during the Mac - September 2020 session. The website basically contains all information for ENT 600 subject. In ECOPRENEUR flipped classroom teaching, resources such as notes, online resources available in the market and videos are arranged according to topics in an online platform. This allows students taking the subject Principles of Entrepreneurship (ENT 600) the freedom to learn at their own pace via interactive media platform which can be reached at http://digitent.my/. The ENT600 class can be conducted on this website virtually anytime, any day without having the hassle of finding the appropriate time or the class slot in a student's assigned class timetable. 


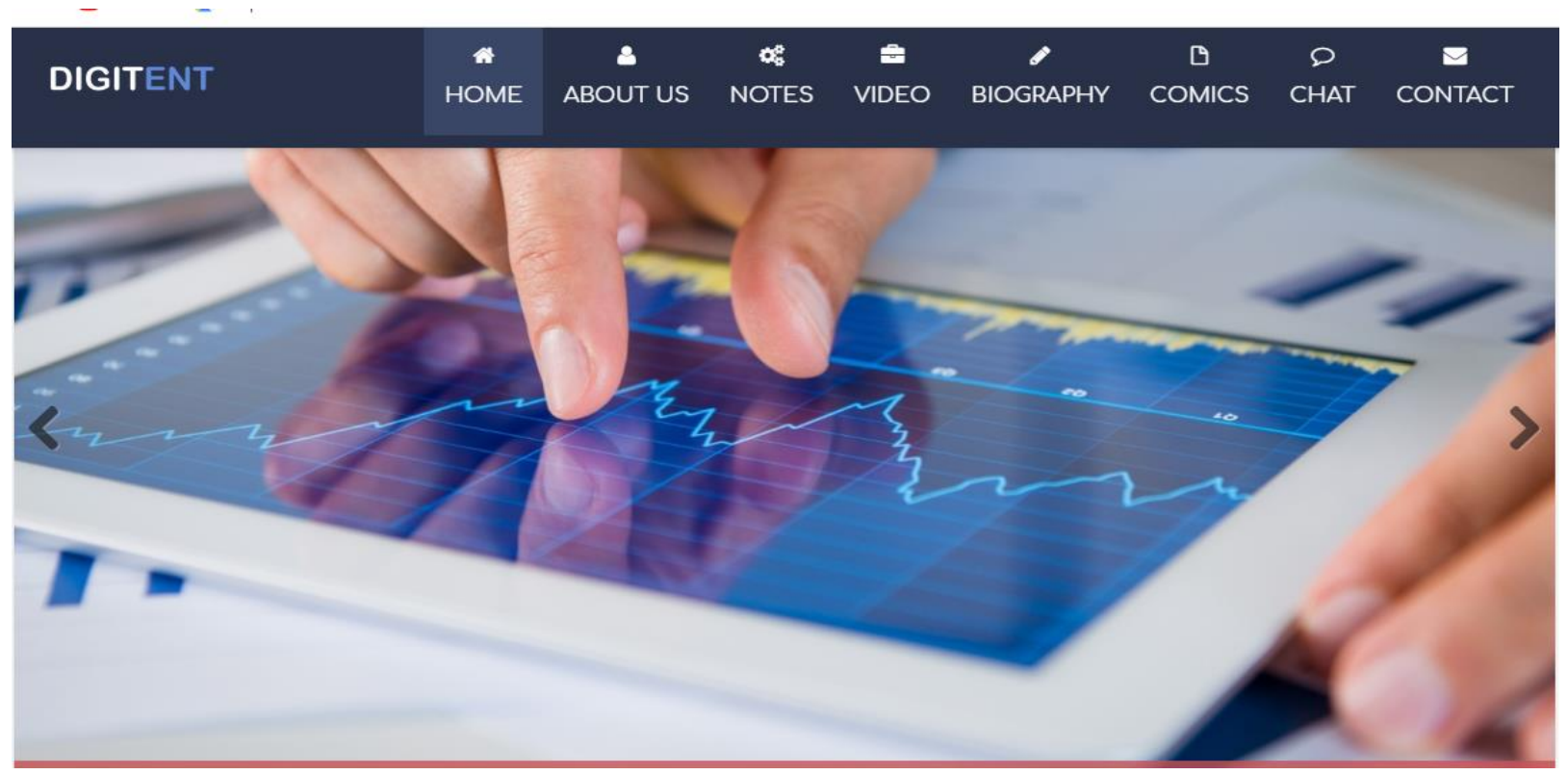

Figure 1: Homepage of ECOPRENEUR

This site can be accessed via either smartphones or laptops. Apart from the internet access, this site requires interaction between students and lecturers for the ENT 600 subject itself where chat rooms are provided if any interaction outside of the classroom is required. Each topic usually starts with a lecturer presented in video form using a platform like PowToon or readily available presentations on YouTube. Next, supplementary content that complements lessons and helps further understanding of key concepts are attached in the website, hence, enabling students to watch videos, go through the other relevant material put online such as educational comics for the summarization of each topic learned, and forums for discussion and quizzes to their students. Class is conducted online using platforms of google meet, zoom or WhatsApp. When students meet the lecturer online during class, it would be more of a question and answer session. Any questions or insights that may arise when the students were going through the online materials were discussed during the class. Students and lecturer pose questions to prompt understanding and discussion of the topic of the subject. The responses provided could be shared with other users in this website. This enables better communication and understanding of the topics. Any additional improvements or updates on this subject will be uploaded by the lecturers themselves and the students. It will be reviewed first by the lecturers then shared with other users. Figure 2 depicts the steps involved in the ECOPRENEUR flipped classroom learning site. 


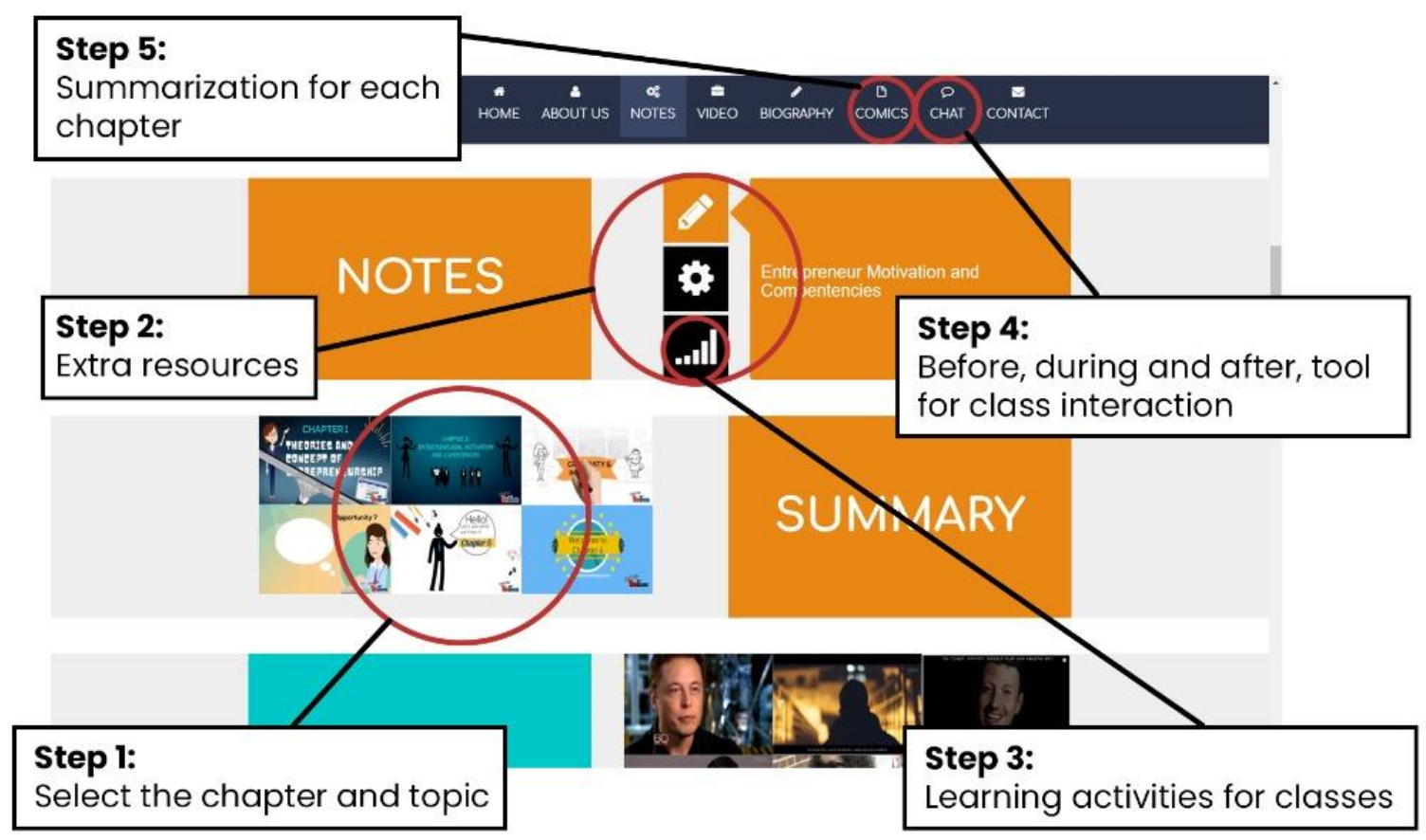

Figure 2 : Steps in ECOPRENEUR flipped classroom learning

While carrying the online discussion, the teacher would be able to identify, for instance students $A, M$ and $Y$ and $a$ few others who have difficulties with Chapter $X$, Therefore, while other students are completing the work assigned for the class, the teacher would be able to contact students $A$, $M$ and $Y$ via video conference and have a more detailed discussion on the topic. This is a more personal approach to overcome their weakness in Chapter $X$. Thus, using the flipped ECOPRENEUR classroom creates a learning opportunity that could help students with varying learning abilities complete the ENT600 course successfully.

Every week students were also told to watch the video (between 10 to 15 mins) on the designated topics and go through other resources attached and complete exercises and quizzes attached during class time. The aim is to help students to learn more about entrepreneurship through a more exciting but simple and fun way. This could be accessed at http://digitent.my/. There were six main chapters that were divided into smaller topics to cover the 14 weeks of the academic session. 
INTERNATIONAL JOURNAL OF ACADEMIC RESEARCH IN PROGRESSIVE EDUCATION AND

DEVELOPMENT

Vol. 9, No. 2, 2020, E-ISSN: $2226-6348$ @ 2020 HRMARS

Table 1:

Lesson 1: Weekly Schedule of Flipped Classroom Learning in ECOPRENEUR

\begin{tabular}{|c|c|c|}
\hline $\begin{array}{l}\text { Week 1-7 } \\
\text { Chapters 1- } 4\end{array}$ & $\begin{array}{l}\text { Before Class } \\
\text { 1. Students go to the NOTES } \\
\text { button and choose Chapters } \\
\text { and Topics as assigned by the } \\
\text { lecturer and watch the videos } \\
\text { on the lecture topic. } \\
\text { 2. Students choose other } \\
\text { resource materials attached } \\
\text { such as journal articles } \\
\text { and/or related theories by } \\
\text { choosing the Pencil, Setting } \\
\text { and Statistic button. } \\
\text { 3. Students pose any } \\
\text { questions they wish to ask in } \\
\text { the Chat Room. }\end{array}$ & $\begin{array}{l}\text { During class: } \\
\text { 1.Question and answer } \\
\text { session between lecturer - } \\
\text { students, students -students } \\
\text { via Google Meet regarding } \\
\text { the topic. } \\
\text { 2. Lecturers assign classwork } \\
\text { to students such as quizzes, } \\
\text { exercises, short written } \\
\text { essays which are to be } \\
\text { submitted by the end of the } \\
\text { class or according to the } \\
\text { lecturer's discretion. } \\
\text { 3. Lecturers form small group } \\
\text { discussions with students } \\
\text { while others do the online } \\
\text { exercise. } \\
\text { 4. Lecturer sums up the day's } \\
\text { lesson } \\
\text { 5.Lecturer briefs students for } \\
\text { materials to explore on } \\
\text { ECOPRENEUR learning } \\
\text { platform on the areas to } \\
\text { cover and exercises to do for } \\
\text { the next class }\end{array}$ \\
\hline Week 8 & $\begin{array}{l}\text { Students conduct self-study } \\
\text { by re-exploring resources } \\
\text { found in ECOPRENEUR } \\
\text { learning portal. }\end{array}$ & $\begin{array}{l}\text { Online Assessments } \\
\text { conducted based on Chapters } \\
1-4\end{array}$ \\
\hline $\begin{array}{l}\text { Week } 9 \text {-14 } \\
\text { Chapter 5-6 }\end{array}$ & $\begin{array}{l}\text { Before Class } \\
\text { 1. Students go to the NOTES } \\
\text { button and choose Chapters } \\
\text { and Topics as assigned by the } \\
\text { lecturer and watch the videos } \\
\text { on the lecture topic. } \\
\text { 2. Students choose the other } \\
\text { resource materials attached } \\
\text { such as journal articles, }\end{array}$ & $\begin{array}{l}\text { During class: } \\
\text { 1.Question and answer } \\
\text { session between lecturer - } \\
\text { students, students - students } \\
\text { via Google Meet regarding } \\
\text { the topic. } \\
\text { 2. Lecturers assign classwork } \\
\text { to students such as quizzes, } \\
\text { exercises, short written }\end{array}$ \\
\hline
\end{tabular}




\begin{tabular}{|c|c|c|}
\hline & $\begin{array}{l}\text { related theories and so on by } \\
\text { choosing the Pencil, Setting } \\
\text { and Statistic button. } \\
\text { 3. Students pose any } \\
\text { questions they wish to ask in } \\
\text { the Chat room. }\end{array}$ & $\begin{array}{l}\text { essays which are to be } \\
\text { submitted by the end of the } \\
\text { class or according to the } \\
\text { lecturer's discretion. } \\
\text { 3. Lecturers form small group } \\
\text { discussions with students } \\
\text { while others do the online } \\
\text { exercise. } \\
\text { 4. Lecturer sums up the day's } \\
\text { lesson } \\
\text { 5.Lecturer briefs students for } \\
\text { materials to explore on } \\
\text { ECOPRENEUR learning portal } \\
\text { on the areas to cover and } \\
\text { exercises to do for the next } \\
\text { class }\end{array}$ \\
\hline Week 15 & $\begin{array}{l}\text { 1.Students conduct self-study } \\
\text { by re-exploring resources } \\
\text { found in ECOPRENEUR } \\
\text { learning portal to prepare for } \\
\text { the final assessment which is } \\
\text { preparation of a Business } \\
\text { Plan. } \\
\text { 3. Students continue to pose } \\
\text { questions in the Chatroom to } \\
\text { be answered by lecturer or } \\
\text { other fellow students. }\end{array}$ & $\begin{array}{l}\text { Presentation of a Business } \\
\text { Plan for final assessment }\end{array}$ \\
\hline
\end{tabular}

\section{Results and Discussion: Student Perceptions}

To check on student's perception of the flipped classroom practiced in ECOPRENEUR, students answered the given survey twice. The first, a structured interview was conducted in midsemester to collect qualitative data to help improve the method and delivery of the ENT600 content. The survey was to gauge the effectiveness of ECOPRENEUR in helping the students to learn online. Three simple questions were asked - i) What works well? ii) What does not work well? and iii) What changes would you suggest?

In response to "What works well?" the most common responses were the ability to watch the video on their own time, pause and rewind content of the video when they do not understand what is being explained. Next, the length of videos which was between 5 to 10 minutes was good to keep the students focused on the content of the video. This is in line with the outcome of a 
study conducted by (Vuong et al., 2018) who suggested that teachers can plan out-of-class learning activities as short as possible to reduce the time pressure on students and to ease the heavy workload. The instructional videos should be short in length, and not too difficult for other tasks such as quizzes or forum discussions. Students will therefore not be overwhelmed by the extra workload. Many also reported that short videos and other supplementary materials in ECOPRENEUR learning portal were easy to access using laptops, tablets and smartphones. Some cited the ability to chat with lecturer and fellow students in the group chat outside the class time gave them the opportunity to go back to certain concepts they did not fully understand the first time. A few students even mentioned that they felt good when the lecturer commended them for helping to answer their peer's queries, which reinforces the material they learned earlier.

Next, for the question, "What does not work well?" Some students reported that some videos that used recorded PowerPoint presentations were nothing different than classroom teaching. However, some said they were comfortable with recorded PowerPoint presentations because the notes from the slides were very useful. So, in response to the question. "What changes would you suggest?" Most students reported they preferred nonlinear presentation tools like Canva, Prezi or Padlet, storytelling software like Powtoon, mind mapping tools, and existing media, such as YouTube videos which were used in certain chapters as it made learning more interactive and interesting in ECOPRENEUR.

The second survey was administered at the end of their academic session of the Mac - July 2020. It consisted of basic demographic questions and a six-question inventory using a Likert - type scale. Students responded by selecting between a range of strongly disagree (1) to strongly agree (5). The survey was conducted online using Google form, and was completely anonymous. A total of 88 students responded to the survey. The items are listed in Table 2.

Table 2: Likert-type survey

Survey questions

1) Teaching that relies solely on books provided by the University is boring.

2) The video and support materials in ECOPRENEUR learning portal were in accordance with the ENT600 syllabus.

3) Learning sessions using the ECOPRENEUR learning portal were exciting

4) I love ECOPRENEUR learning portal Videos because they were informative and interesting.

5) I like the support materials in the ECOPRENEUR learning portal because it provides information related to the topics.

6) The use of materials from the ECOPRENEUR learning portal helped me to produce a good final project paper for ENT600.

Overall, the flipped classroom method used in ECOPRENEUR was very well-received by students. The overall results of the second survey is as listed in Table 2 as below. 
INTERNATIONAL JOURNAL OF ACADEMIC RESEARCH IN PROGRESSIVE EDUCATION AND DEVELOPMENT

Vol. 9, No. 2, 2020, E-ISSN: $2226-6348$ @ 2020 HRMARS

\begin{tabular}{|c|c|c|c|c|c|c|}
\hline Items & 1 & 2 & 3 & 4 & 5 & $\begin{array}{c}\text { Total } \\
\text { (N \& \%) }\end{array}$ \\
\hline $\begin{array}{l}\text { 1. Teaching that relies solely on } \\
\text { books provided by the University is } \\
\text { boring }\end{array}$ & $\begin{array}{l}0 \\
0 \%\end{array}$ & $\begin{array}{l}0 \\
0 \%\end{array}$ & $\begin{array}{l}0 \\
0 \%\end{array}$ & $\begin{array}{l}80 \\
91 \%\end{array}$ & $\begin{array}{l}8 \\
9 \%\end{array}$ & $\begin{array}{l}88 \\
100 \%\end{array}$ \\
\hline $\begin{array}{l}\text { 2. The video and support materials } \\
\text { in ECOPRENEUR learning portal } \\
\text { were in accordance with the } \\
\text { ENT } 600 \text { syllabus }\end{array}$ & $\begin{array}{l}0 \\
0 \%\end{array}$ & $\begin{array}{l}0 \\
0 \%\end{array}$ & $\begin{array}{l}10 \\
12 \%\end{array}$ & $\begin{array}{l}74 \\
84 \%\end{array}$ & $\begin{array}{l}4 \\
5 \%\end{array}$ & $\begin{array}{l}88 \\
100 \%\end{array}$ \\
\hline $\begin{array}{l}\text { 3.Learning sessions using the } \\
\text { ECOPRENEUR learning portal } \\
\text { were exciting }\end{array}$ & $\begin{array}{l}0 \\
0 \%\end{array}$ & $\begin{array}{l}0 \\
0 \%\end{array}$ & $\begin{array}{l}0 \\
0 \%\end{array}$ & $\begin{array}{l}84 \\
95 \%\end{array}$ & $\begin{array}{l}4 \\
5 \%\end{array}$ & $\begin{array}{l}88 \\
100 \%\end{array}$ \\
\hline $\begin{array}{l}\text { 4.I like the videos in the } \\
\text { ECOPRENEUR learning portal } \\
\text { because they were informative and } \\
\text { interesting. }\end{array}$ & $\begin{array}{l}0 \\
0 \%\end{array}$ & $\begin{array}{l}0 \\
0 \%\end{array}$ & $\begin{array}{l}4 \\
5 \%\end{array}$ & $\begin{array}{l}80 \\
91 \%\end{array}$ & $\begin{array}{l}4 \\
5 \%\end{array}$ & $\begin{array}{l}88 \\
100 \%\end{array}$ \\
\hline $\begin{array}{l}\text { 5. I like the support materials in the } \\
\text { ECOPRENEUR learning portal } \\
\text { because they were informative }\end{array}$ & $\begin{array}{l}0 \\
0 \%\end{array}$ & $\begin{array}{l}0 \\
0 \%\end{array}$ & $\begin{array}{l}0 \\
0 \%\end{array}$ & $\begin{array}{l}84 \\
95 \%\end{array}$ & $\begin{array}{l}4 \\
5 \%\end{array}$ & $\begin{array}{l}88 \\
100 \%\end{array}$ \\
\hline $\begin{array}{l}\text { 6. The use of materials from the } \\
\text { ECOPRENEUR learning portal } \\
\text { helped me to produce a good final } \\
\text { project paper for ENT } 600 \text {. }\end{array}$ & $\begin{array}{l}0 \\
0 \%\end{array}$ & $\begin{array}{l}0 \\
0 \%\end{array}$ & $\begin{array}{l}2 \\
2 \%\end{array}$ & $\begin{array}{l}82 \\
93 \%\end{array}$ & $\begin{array}{l}4 \\
5 \%\end{array}$ & $\begin{array}{l}88 \\
100 \%\end{array}$ \\
\hline
\end{tabular}

In response to item1: "Teaching that relies solely on books provided by the university is boring." $100 \%$ of students responded favorably by responding either 'agree' (91\%) or 'strongly agree' (9\%) as seen in Figure 3 below. Below are excerpts of the findings based on the survey questionnaire posed to students.

Figure 3: Excerpts of findings from questionnaire



1-strongly disagree 2 . Disagree 3 -neutral 4 - agree 5 -strongly agree

For item 2: "The video and support materials in ECOPRENEUR learning portal were in accordance with the ENT600 syllabus". Again 84\% of the respondents selected 'agree' and another 5\% selected 'strongly agree' with the statement and $12 \%$ responded they are not sure. 
Vol. 9, No. 2, 2020, E-ISSN: $2226-6348$ @ 2020 HRMARS

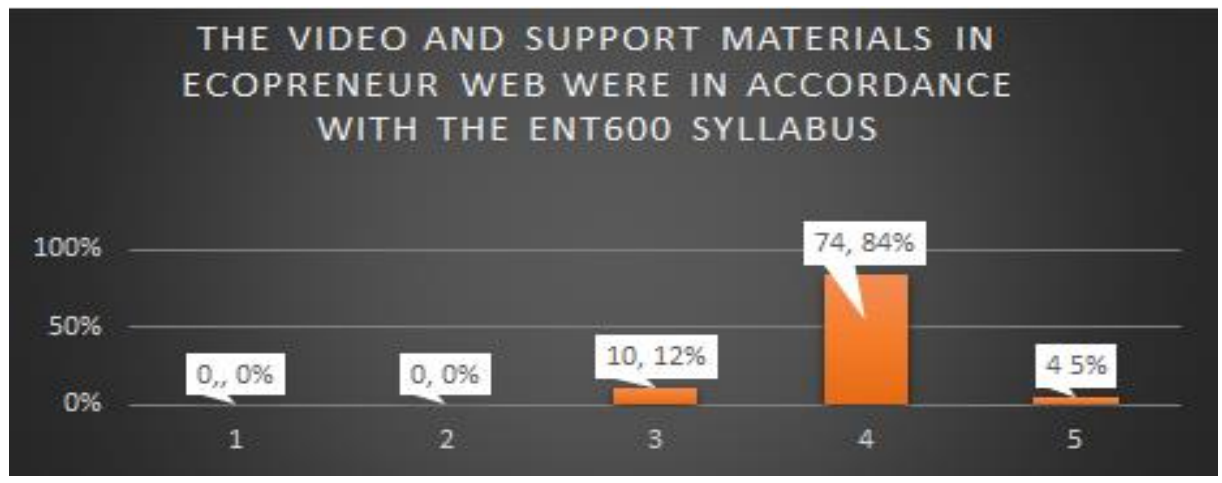

1-strongly disagree 2 . disagree 3 -neutral 4 - agree 5 -strongly agree

Similarly, for Item 3: "Learning sessions using the ECOPRENEUR learning portal were exciting." students responded very positively whereby $95 \%$ chose 'agree' and another $5 \%$ chose 'strongly agree". None of the respondents choose "not sure or disagreed with the statement. Thus, proclaiming that indeed the learning experience using the ECOPRENEUR was very positive.

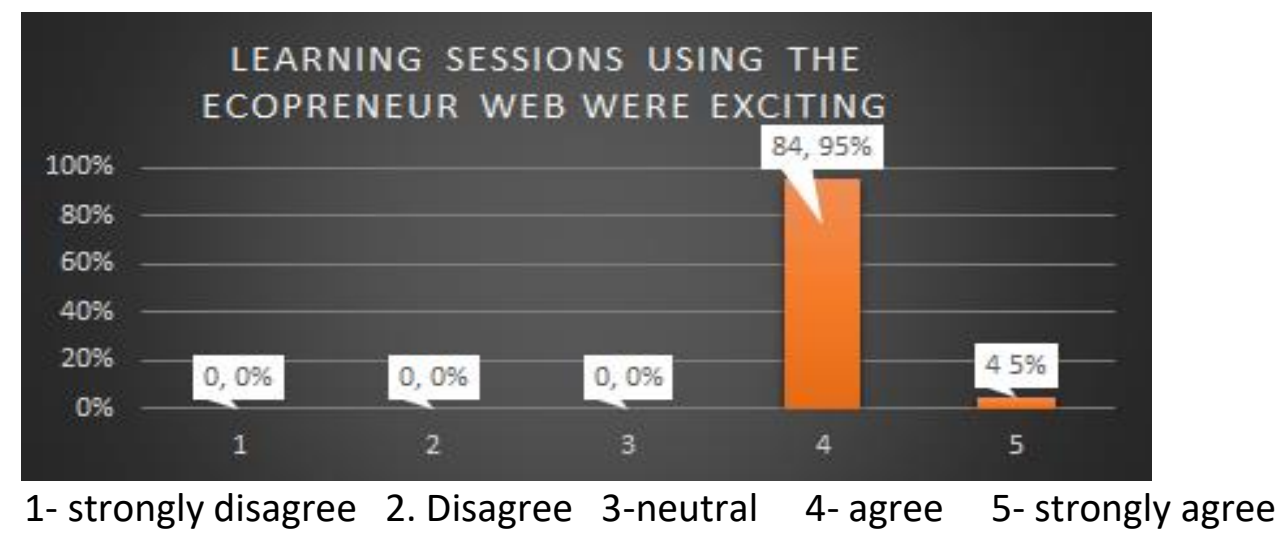

For Item 4, students were asked to respond to the statement." I liked the videos in the ECOPRENEUR learning portal because they were informative and interesting." $91 \%$ of the respondents chose 'agree' and another 5\% chose totally agree. Only a small percentage of 5\% said they were not sure. The item was asked to gauge whether the short videos which were less than 10 minutes long was acceptable for the students. This finding is in line with Vuong et al., (2018) whose study mentioned that pre-class activities, especially the instructional videos, should be kept short enough to avoid distraction, and well planned to make content readily digestible. 


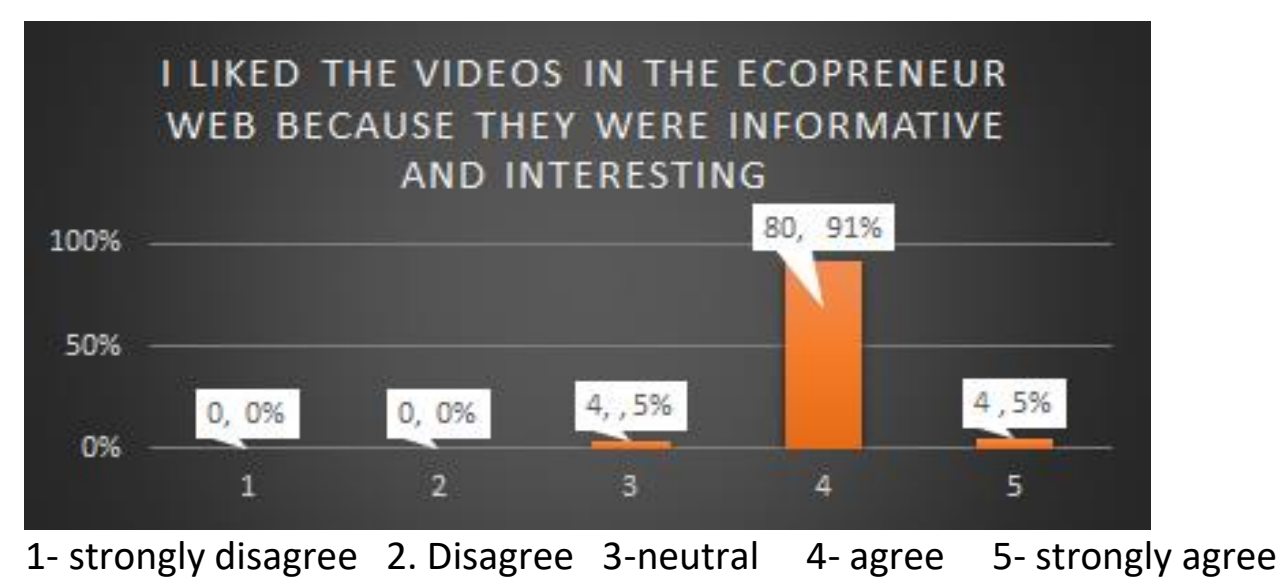

For Item 5: I like the support materials in the ECOPRENEUR learning portal because they are informative and helpful for ENT600. This question was asked to check on the usefulness of the materials in the ECOPRENEUR learning portal. Again $100 \%$ of the respondents responded positively by selecting 'agree' (95\%) and strongly agree' (5\%).

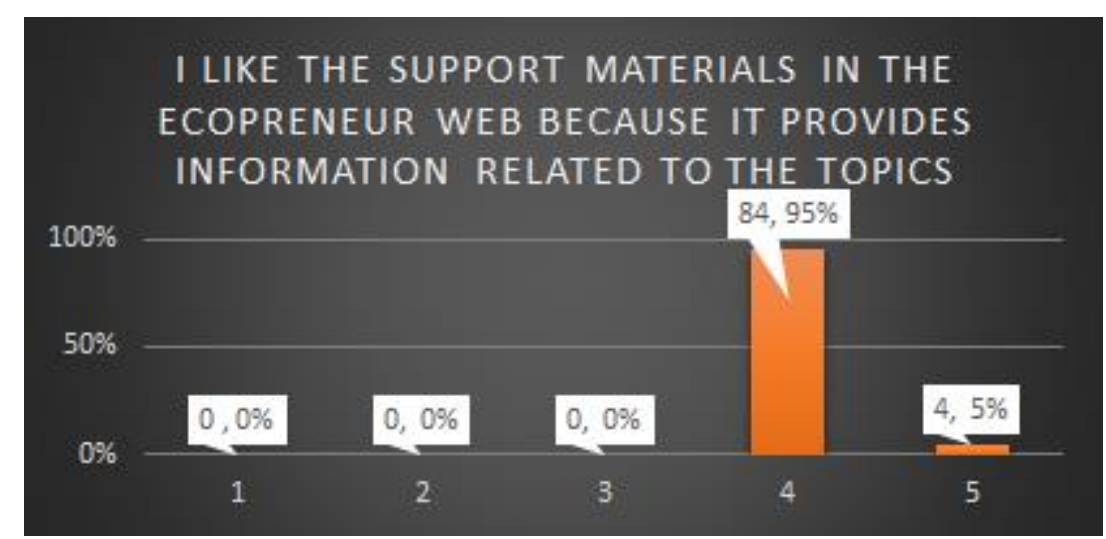

1-strongly disagree 2 . Disagree 3 -neutral $\quad 4$-agree $\quad$ 5-strongly agree

Finally, for Item 6 (The use of materials from the ECOPRENEUR learning portal helped me to produce a good final project paper for ENT600) was included in the survey because ultimately the success of any learning tool is to match it with the ability of students to produce a good final project paper for the ENT 600 . The results from the survey reflected that $98 \%$ of the students responded positively to the statement with 93\% stating 'agree' and 5\% 'totally agree" as seen in Table 3. 


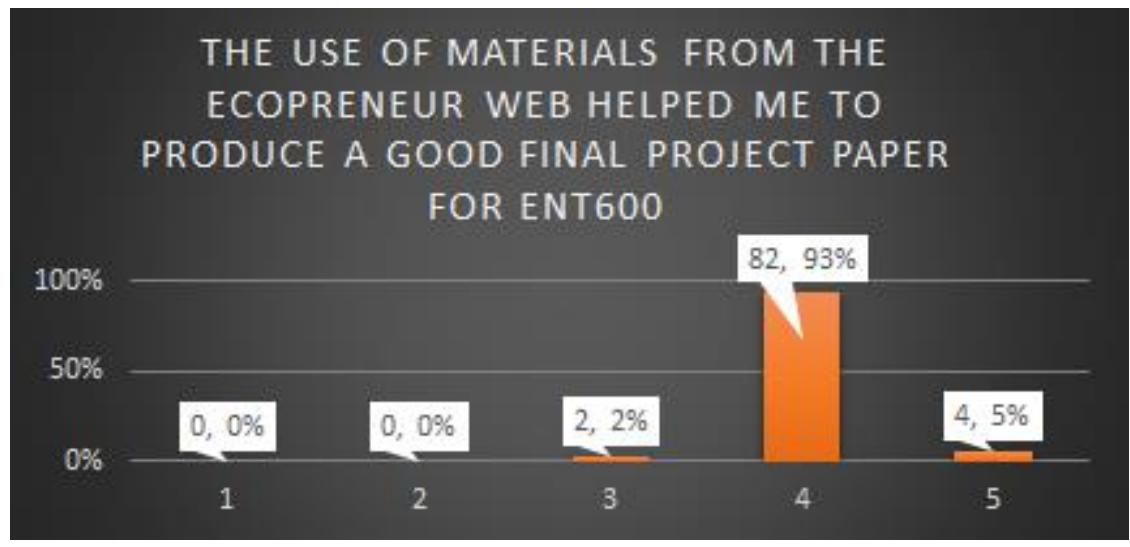

1- strongly disagree 2. Disagree 3-neutral 4-agree 5-strongly agree

This finding was matched with the final grade obtained by the students for ENT600 for the semester Mac- July2020. Table 3 and Figure 5 reflect on results of students who used ECOPRENEUR as compared to students from the previous semester who did not use the ECOPRENEUR learning portal.

The final grade for the subject code ENT600 was compared with another group of students who learnt the same subject with the same lecturer without using the ECOPRENEUR learning portal. The results are shown in Table 3 and Figure 5

\begin{tabular}{|c|c|c|c|c|c|c|c|c|}
\hline \multicolumn{4}{|c|}{ Learning without using Ecopreneur website } & \multirow[b]{3}{*}{ Total } & \multirow{2}{*}{\multicolumn{3}{|c|}{$\begin{array}{c}\text { Learning using Ecopreneur website } \\
\text { Groups } \\
\end{array}$}} & \multirow[b]{3}{*}{ Total } \\
\hline \multirow[t]{2}{*}{ Grade } & \multicolumn{3}{|c|}{ Groups } & & & & & \\
\hline & M3CS2305A & M3 CS230 5D & M3CS 2466B & & M3CS2305B & M3CS230 5C & M3 CS246 6A & \\
\hline A+ & 0 & 0 & 0 & 0 & 0 & 0 & 0 & 0 \\
\hline A & 0 & 0 & 0 & 0 & 31 & 29 & 26 & 86 \\
\hline A- & 0 & 0 & 3 & 3 & 0 & 0 & 0 & 0 \\
\hline $\mathrm{B}+$ & 28 & 2 & 15 & 45 & 0 & 2 & 0 & 2 \\
\hline B & 7 & 0 & 2 & 9 & 0 & 0 & 0 & 0 \\
\hline B- & 0 & 25 & 10 & 35 & 0 & 0 & 0 & 0 \\
\hline $\mathrm{C}+$ & 0 & 4 & 0 & 4 & 0 & 0 & 0 & 0 \\
\hline C & 0 & 0 & 0 & 0 & 0 & 0 & 0 & 0 \\
\hline C- & 0 & 0 & 0 & 0 & 0 & 0 & 0 & 0 \\
\hline \multirow[t]{2}{*}{ D } & 0 & 0 & 0 & 0 & 0 & 0 & 0 & 0 \\
\hline & 35 & 31 & 30 & 96 & 31 & 31 & 26 & 88 \\
\hline
\end{tabular}

Table 3: Final grade results comparison between controlled group and experimental group 
Vol. 9, No. 2, 2020, E-ISSN: $2226-6348$ @ 2020 HRMARS

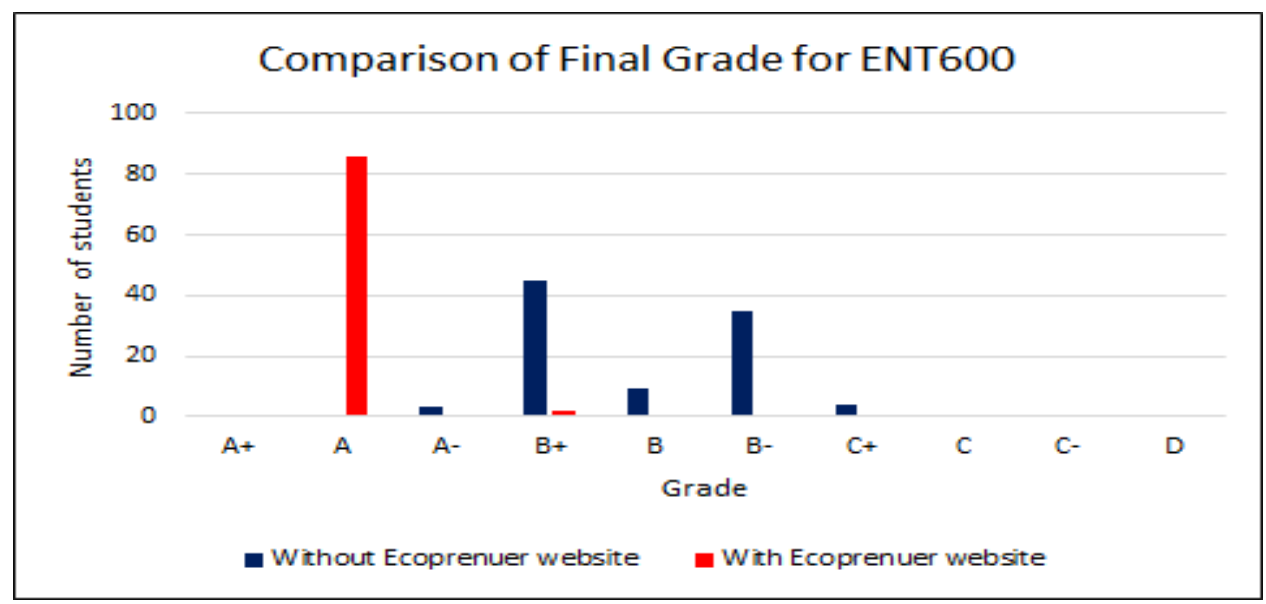

Figure 5: Comparison of final grade results

As seen in Figure 5, students from the group that used ECOPRENEUR learning portal that used the flipped classroom method to learn the subject Principles of Entrepreneurship (ENT 600) enabled 86 (97.72\%) out of the 88 students score " $A$ " for their final project paper as compared to none (zero-0\%) from the group that learned ENT600 without the support from ECOPRENEUR learning web. This finding implies that a fully online flipped learning method can be used for the teaching and learning for ENT600 and students have benefited from the using the ECOPRENEUR learning portal.

\section{Conclusion}

This paper has discussed the use of flipped classroom method to learn the subject Principles of Entrepreneurship (ENT 600) on a full online platform: ECOPRENEUR. Students' response to their learning experience was reported. This study found that students as a whole had positive perceptions on the digital ECOPRENEUR learning platform that used a fully online flipped classroom learning method, and their final grade for the subject ENT600 vouched for the success of the use of flipped classroom and ECOPRENEUR learning platform. A key finding of this study was that flipped classroom can be successfully carried out in a completely digital platform without having to meet face-to-face in a physical classroom. The higher order thinking skills emphasized in the flipped classroom may have helped the vast improvement in the ability of students to produce better final academic paper.

This study has also shown that despite being completely flipped, the communication extended by their lecturer ensured that the students still received a human touch. This personal approach was found to help some students who needed further instruction especially in understanding Chapter X. Thus, using the flipped classroom like the ECOPRENEUR can provide learning opportunities for students who are independent learners as well those who need guidance. Furthermore, this study focused on ENT 600, an entrepreneurship course. Future researchers can examine how other courses can be taught in a similar medium of instruction to yield successful learning. In this pandemic environment, it is important that course instructors engage learners through varied online teaching materials. 
INTERNATIONAL JOURNAL OF ACADEMIC RESEARCH IN PROGRESSIVE EDUCATION AND

DEVELOPMENT

Vol. 9, No. 2, 2020, E-ISSN: $2226-6348$ @ 2020 HRMARS

\section{References}

Chernev, B. (2020). 27 Astonishing E-learning Statistics for 2020 [Web log post]. Retrieved September 9, 2020, from https://techjury.net/blog/elearning-statistics/\#gref

Ganguly, I. (2019). Flipped Classroom Has Lead To Flipped Blooms Taxonomy - A Case Study In Teaching Language. International Journal of English Learning \& Teaching Skills, 2(2), 10611070. doi:10.15864/ijelts.2203

Kim, M., Jung, E., De Siqueira, A., \& Huber, L. (2016). An Investigation into Effective Pedagogies in a Flipped Classroom: A Case Study. International Journal of E-Learning and Distance Education, 32(2). doi:file:///C:/Users/user/Downloads/964-Article Text-5859-5-1020190328.pdf.

McLaughlin, J. E., Rhoney, D. H. (2015). Comparison of an interactive elearning preparatory tool and a conventional downloadable handout used within a flipped neurologic pharmacotherapy lecture. Curr Pharm Teach Learn. 7(1), 12-19

O'Flaherty, J., \& Phillips, C. (2015). The use of flipped classrooms in higher education: A scoping review. The Internet and Higher Education, 25, 85-95.

Perinpasingam, T., Chin, H. L., Supramaniam, K. (2019). Needs Analysis of Teacher's use of the Interactive White Board. (pp.133-142). Malaysia: UPM Press.

Shanthi, A., Thayalan, X., \& Suppiah, P. (2019). Speech Acts and Discourse Pattern in Information Sharing Practice in Malaysian Web-Forums. In KnE Social Sciences (Vol. 2019, pp. 888-901). https://doi.org/10.18502/kss.v3i19.4915

Shanthi, A., Thayalan, X., \& Xavierine, J. (2018). Features of Trust in Online Guanxi among Malaysian Web-Forum Members Features of Trust in Online Guanxi among Malaysian Web- Forum Members.

Vuong, N. H. A., Tan, C. K., \& Lee, K. W. (2018). Students' Perceived Challenges of Attending a Flipped EFL Classroom in Viet Nam. Theory and Practice in Language Studies, 8(11), 1504. https://doi.org/10.17507/tpls.0811.16

Xu, Z., \& Shi, Y. (2018). Application of Constructivist Theory in Flipped Classroom - Take College English Teaching as a Case Study. Theory and Practice in Language Studies, 8(7), 880. doi:10.17507/tpls.0807.21 